\title{
A critical look at technological innovation typology and innovativeness terminology: a literature review
}

\author{
Rosanna Garcia*1 ${ }^{1}$, Roger Calantone ${ }^{2}$ \\ Department of Marketing \& Supply Chain Management, Michigan State University, East Lansing, MI, USA
}

Received 30 September 2001; accepted 20 May 2001

\begin{abstract}
A plethora of definitions for innovation types has resulted in an ambiguity in the way the terms 'innovation' and 'innovativeness' are operationalized and utilized in the new product development literature. The terms radical, really-new, incremental and discontinuous are used ubiquitously to identify innovations. One must question, what is the difference between these different classifications? To date consistent definitions for these innovation types have not emerged from the new product research community. A review of the literature from the marketing, engineering, and new product development disciplines attempts to put some clarity and continuity to the use of these terms. This review shows that it is important to consider both a marketing and technological perspective as well as a macrolevel and microlevel perspective when identifying innovations. Additionally, it is shown when strict classifications from the extant literature are applied, a significant shortfall appears in empirical work directed toward radical and really new innovations. A method for classifying innovations is suggested so that practitioners and academics can talk with a common understanding of how a specific innovation type is identified and how the innovation process may be unique for that particular innovation type. A recommended list of measures based on extant literature is provided for future empirical research concerning technological innovations and innovativeness. () 2002 PDMA. All rights reserved.
\end{abstract}

"A rose is a rose is a rose. And a rose by any other name would smell just as sweet."

Gertrude Stein \& William Shakespeare

\section{Introduction}

Academics generally believe that they have begun to understand the process of developing innovations and it doesn't matter what they call them; new innovations smell just as sweet by any other name. The innovation process has been identified for radical, incremental, really new, discontinuous, and imitative innovations, as well as for architectural, modular, improving, and evolutionary innovations. Based on solid empirical research, normative strategies have been suggested for each of these different types of innovations. Yet, one has to ask, what is the difference between a radical innovation, a really new product innovation, and a discontinuous innovation? What is the difference between an incremental innovation and an imitative innovation? Just as important, does it matter how innovations are labeled?

No less than fifteen constructs and at least 51 distinct

\footnotetext{
* Corresponding author. Tel.: +1-517-353-6381; fax: +1-517-432-1112.
}

E-mail address: garciar8@msu.edu (R. Garcia). scale items have been used in just 21 empirical studies in the new product development (NPD) literature that model product innovativeness (see Table 1 and Appendix A). This lack of consistency in operationalizing 'innovationativeness' has resulted in the interchangeable use of the constructs 'innovation' and 'innovativeness' to define innovation types. Although this may seem to be an insignificant point, this has led to incongruent categorizations of innovation typology and widespread confusion as to what empirical studies are actually reporting. An innovation that one researcher may term 'really new' is termed 'radical' or 'discontinuous' by another researcher. Additionally, there is no consistent delineation on what is considered 'high', 'moderate' and 'low' degree of innovativeness and if that correlates to the categorizations of 'radical', 'really new', and 'incremental' innovations or some other typology.

Although this lack of conformance in defining 'innovation' and 'innovativeness' has been recognized [7,21,25,27, 36] there has been no embracement of any consistent dimensions of these constructs. This may be due to the fact that innovations are researched from many scholastic communities and address each community's select audience. 
Table 1

Constructs used to model product innovation/innovativeness

\begin{tabular}{ll}
\hline Construct & Study* \\
\hline - Product innovativeness & $2,6,7,9,12,13,15,17$ \\
- Radicalness (discontinuous) & $11,14,16,18,20,21$ \\
- Newness to firm & $1,6,10,13,19$ \\
- Technical content & 4,8 \\
- Newness to market & 19 \\
- Newness of technology & 19 \\
- Newness to customer & 10 \\
- Product uniqueness & 1 \\
- Product (superiority) & 1 \\
- Synergy (fit) & 1 \\
- Product/market fit & 6 \\
- Marketing task similarity & 3 \\
- Product complexity & 3 \\
- Development complexity & 3 \\
- Product type & 5 \\
\hline
\end{tabular}

* Some studies used more than one construct.

1. Cooper (1979)

2. Lawton \& Parasuraman (1980)

3. More (1982)

4. Maidique \& Zirger (1984)

5. Yoon \& Lilien (1985)

6. Cooper \& de Brentani (1991)

7. Kleinschmidt \& Cooper (1991)

8. Lee \& Na (1994)

9. Ali, Krapfel, \& LaBahn (1995)

10. Atuahene-Gima (1995)

11. Green, Gavin, \& Aiman-Smith (1995)

12. Olson, Walker \& Ruekert (1995)

13. Mishra, Kim, \& Lee (1996)

14. Souder \& Song (1997)

15. Schmidt \& Calantone (1998)

16. Colarelli O'Connor (1998)

17. Song \& Montoya-Weiss (1998)

18. Veryzer (1998)

19. Goldenberg, Lehman, \& Mazursky (1999)

20. Kessler \& Chakrabarti (1999)

21. Chandy \& Tellis (2000)

However, a large proportion of significant findings regarding innovations have originated in the last 15 years from the research of the Journal of Product Innovation Management with its diverse base of engineers, marketers, product managers, and R\&D team members [8]. For this reason, it is important that a consistent set of working definitions evolve from this community of researchers.

Why is it necessary to have a consistent typology for identifying innovations? It is only possible to advance our knowledge of innovations by understanding what is the difference between a radical innovation, a really new innovation, and an incremental innovation. This literature review will demonstrate how inconsistencies in labeling innovations have significantly contributed to a lack of academic advancements regarding the NPD process of different types of innovations. NPD researchers have identified various innovation types on an ad hoc basis, and this has resulted in research myopia. More bluntly, researchers often believe that their work is 'new' and 'important' when in- stead it just relabels/redefines/reiterates findings from previous studies with different labeling of innovations. Findings from other fields (organizational behavior, engineering, strategic management) are often overlooked because they emphasize a 'different' type of innovation. A recent metaanalysis by Henard \& Szymanski [26] emphasizes this point as it may exclude the findings from other disciplines because of this identification crisis.

In empirical research, hypothesis building regarding innovation types has also discounted relevant prior research that does not use the same terminology as the research being undertaken. This leads to 'new' findings that are in fact rehashes of previous work. Additionally, this lack of consistency can lead to the reversal of causal notions in hypothesis building. Where innovativeness may be modeled as the cause it may be more appropriately modeled as the effect. The identification of innovation types and their influence on the market place is really a problem as old as classical economics [51]! To ignore these distinctions is to turn one's back, literally, on sixty-five years of research on the innovation process.

Because new product researchers have not found consistency in labeling and identifying innovations, we cannot expect practitioners to have learned from our research endeavors. Managers looking for an understanding of how to address the idiosyncratic problems associated with radical innovations will have difficulties finding the holy grail from our research efforts. Managers see more conflict in empirical results than is factually true, natural, or even possible in empirical research. Thus, they make choices of which research finding is 'relevant' based on the presentation style, the 'hot topic' of the meeting, or whatever supports their personal motivations or that of their current consultant. One cannot expect managers to embrace confusing conflicting results. For example, a manager assigned to a new product team must first discern if he/she is working with a radical, really new, discontinuous, disruptive, incremental, or imitative innovation. Upon making this distinction (if even possible), he/she will then disregard a substantial and significant amount of research findings that may have helped advance the NPD project.

For empirical research to have an impact on practice, it should be focused, clear and report 'true' differences, not results biased by mis-defined outcomes. For these reasons, we believe that this literature review can be useful for facilitating future advancements in the NPD process. The purpose of this article is to delineate the domain of the constructs 'innovation' and 'innovativeness', to provide an operational definition, and to introduce a comprehensive framework for directing future research. We draw on new product literature in marketing, management, and engineering to provide a candid review of the usage of the terminology technological 'innovation' and 'innovativeness'. Instead of inventing yet another original typology, we will synthesize a categorization that provides a parsimonious conceptualization of the overarching factors of interest to 
new product researchers and practitioners concerning new product/process/service innovations.

\section{Inovation and innovativeness explicated}

\section{1. 'Innovation' defined.}

In order to begin to identify innovation types, it is first important to define a 'technological innovation'. Engineering, marketing, management and even economics provide unique spins as to what is considered an innovation. A review of this literature reveals that the 1991 OECD [44] study on technological innovations best captures the essence of innovations from an overall perspective: 'Innovation' is an iterative process initiated by the perception of a new market and/or new service opportunity for a technologybased invention which leads to development, production, and marketing tasks striving for the commercial success of the invention.

This definition addresses two important distinctions: [1] the 'innovation' process comprises the technological development of an invention combined with the market introduction of that invention to end-users through adoption and diffusion, and [2] the innovation process is iterative in nature and thus, automatically includes the first introduction of a new innovation and the reintroduction of an improved innovation. This iterative process implies varying degrees of innovativeness and thus, necessitates a typology to describe different types of innovations. As pointed out by an anonymous reviewer, the OECD definition also references 'technology-based inventions'. Technological innovations are those innovations that embody inventions from the industrial arts, engineering, applied sciences and/or pure sciences. Examples include innovations from the electronics, aerospace, pharmaceuticals, and information systems industries.

It is important to elucidate that an invention does not become an innovation until it has processed through production and marketing tasks and is diffused into the marketplace $[19,34,53]$. "The solution to a basic scientific puzzle or the invention of a new "product" only in a laboratory setting makes no direct economic contribution. Innovation includes not only basic and applied research but also product development, manufacturing, marketing, distribution, servicing, and later product adaptation and upgrading" [53 p. 1]. A discovery that goes no further than the laboratory remains an invention. A discovery that moves from the lab into production, and adds economic value to the firm (even if only cost savings) would be considered an innovation. Thus, an innovation differs from an invention in that it provides economic value and is diffused to other parties beyond the discoverers.

The continual evolution of innovations is the iterative nature referenced in the OECD definition. Utterback and Abernathy [60] describe the iterative process of innovation.
"A basic idea underlying the proposed model of product innovation is that products will be developed over time in a predictable manner with initial emphasis on product performance, then emphasis on product variety and later emphasis on product standardization and costs" [p. 642]. This iterative nature results in a variety of different innovation types, typically called 'radical innovations' for products at the early stages of diffusion and adoption and incremental innovations' at the advanced stages of the product life cycle. Innovations do not occur just during the production development phases but also may occur during the diffusion process in which a product or process may undergo continual improvements and upgrades. "Diffusion is seldom, if ever, a simple process of replication by unimaginative imitators" [18 p. 305].

A clarification of the differentiation between process innovations and the innovation process is also worthwhile. "A production process [innovation] is the system of process equipment, work force, task specification, material inputs, work and information flows, and so forth that are employed to produce a product or service" [60 p. 641]. Once the production process has become standardized for product innovations, process innovations will evolve to improve the output productivity. Classic examples of process innovations are the float glass process for flat-sheet glass manufacturing and the Bessemer process for converting iron to steel, which revolutionized the steel industry. The primary focus of 'process innovations' is the efficiency improvement of the production process for 'product innovations' [59]. What is not evident and can lead to confusion between distinguishing between process innovations and the innovation process is that process innovations can lead to new product innovations.

\section{2. 'Innovativeness' defined}

'Innovativeness' is most frequently used as a measure of the degree of 'newness' of an innovation. 'Highly innovative' products are seen as having a high degree of newness and 'low innovative' products sit at the opposite extreme of the continuum. However, little continuity exists in the new product literature regarding from whose perspective this degree of newness is viewed and what is new. Although the majority of research takes a firm's perspective toward newness, others look at new to the world [54], new to the adopting unit [15], new to the industry [10], new to the market [31,38], and new to the consumer [4], (see Table 2). This relative nature of defining innovativeness has contributed to the lack of advancement in understanding the NPD process as studies cannot be compared across different units of analysis. The bouncing point of view of newness, creates distinctive, unique studies that never achieve the status of "re"-search.

Despite the varying perspectives for 'innovativeness' a single consistency does exist; it is always modeled as the degree of discontinuity in marketing and/or technological 
Table 2

Newness factors

\begin{tabular}{|c|c|c|c|c|c|c|c|c|c|c|c|c|c|c|c|c|c|c|c|c|c|}
\hline & 1 & 2 & 3 & 4 & 5 & 6 & 7 & 8 & 9 & 10 & 11 & 12 & 13 & 14 & 15 & 16 & 17 & 18 & 19 & 20 & 21 \\
\hline \multicolumn{22}{|l|}{ New to: } \\
\hline New to the world & & & & & & & $\mathrm{x}$ & $\mathrm{x}$ & & $\mathrm{x}$ & & $\mathrm{x}$ & & & & & & & & & \\
\hline New to the industry & & & & $\mathrm{x}$ & & & & & & & $\mathrm{x}$ & & & & $\mathrm{x}$ & $\mathrm{x}$ & & & & & \\
\hline New to scientific community & & & & & & $\mathrm{x}$ & & & & & $\mathrm{x}$ & & & & & & & & & & \\
\hline New to the market(place) & $\mathrm{x}$ & & & $\mathrm{x}$ & $\mathrm{x}$ & & & $\mathrm{x}$ & $\mathrm{x}$ & & & $\mathrm{x}$ & $\mathrm{x}$ & & $\mathrm{x}$ & & & & $\mathrm{x}$ & & \\
\hline New to the firm & $\mathrm{x}$ & & $\mathrm{x}$ & & & $\mathrm{x}$ & $\mathrm{x}$ & & & & $\mathrm{x}$ & $\mathrm{x}$ & & & & $\mathrm{x}$ & & & $\mathrm{x}$ & & \\
\hline New to the customer & & & & & & & & & $\mathrm{x}$ & & & $\mathrm{x}$ & & & & & & & & & \\
\hline \multicolumn{22}{|l|}{ New what: } \\
\hline New technology & $\mathrm{x}$ & & $\mathrm{x}$ & $\mathrm{x}$ & & $\mathrm{x}$ & $\mathrm{x}$ & $\mathrm{x}$ & $\mathrm{x}$ & & $\mathrm{x}$ & $\mathrm{x}$ & $\mathrm{x}$ & & & $\mathrm{x}$ & & $\mathrm{x}$ & $\mathrm{x}$ & $\mathrm{x}$ & $\mathrm{x}$ \\
\hline New product line & $\mathrm{x}$ & $\mathrm{x}$ & $\mathrm{x}$ & & $\mathrm{x}$ & $\mathrm{x}$ & & & & $\mathrm{x}$ & $\mathrm{x}$ & $\mathrm{x}$ & $\mathrm{x}$ & & $\mathrm{x}$ & & & & & & \\
\hline New product benefits/features & $\mathrm{x}$ & & & & & & & & $\mathrm{x}$ & & & & & $\mathrm{x}$ & $\mathrm{x}$ & & & & & & \\
\hline New product design & & $\mathrm{x}$ & & & & & $\mathrm{x}$ & $\mathrm{x}$ & & $\mathrm{x}$ & & & & & $\mathrm{x}$ & & & & & $\mathrm{x}$ & \\
\hline New process & $\mathrm{x}$ & & $\mathrm{x}$ & & $\mathrm{x}$ & $\mathrm{x}$ & & $\mathrm{x}$ & & & & & $\mathrm{x}$ & & $\mathrm{x}$ & & & & & & \\
\hline New service & & & & & & $\mathrm{x}$ & & & & & & & & & & & & & & & \\
\hline New competition & $\mathrm{x}$ & & $\mathrm{x}$ & & $\mathrm{x}$ & $\mathrm{x}$ & & & & & & & $\mathrm{x}$ & & & & & & & & \\
\hline New customers & $\mathrm{x}$ & & $\mathrm{x}$ & & & $\mathrm{x}$ & & & & & & & $\mathrm{x}$ & & & & & & & & \\
\hline New customer need & & & & & & $\mathrm{x}$ & & & & & & & $\mathrm{x}$ & & & & & & & & \\
\hline New consumption patterns & $\mathrm{x}$ & $\mathrm{x}$ & & & & & & & & & & & & $\mathrm{x}$ & & & & & & & \\
\hline New uses & $\mathrm{x}$ & & & & & & & & & & & & & $\mathrm{x}$ & & & & $\mathrm{x}$ & & & \\
\hline New improvements/changes & & & & & & $\mathrm{x}$ & $\mathrm{x}$ & $\mathrm{x}$ & & & & $\mathrm{x}$ & & & & & & & & & \\
\hline New development skills & & & & & & & & & & & $\mathrm{x}$ & & & & & & & & $\mathrm{x}$ & & \\
\hline $\begin{array}{l}\text { New marketing/sales/ } \\
\text { distribution skills }\end{array}$ & $\mathrm{x}$ & & $\mathrm{x}$ & & & $\mathrm{x}$ & & & & & $\mathrm{x}$ & & $\mathrm{x}$ & & $\mathrm{x}$ & & & & & & \\
\hline New managerial skills & & & & & & $\mathrm{x}$ & & & & & & & & & & & & & & & \\
\hline $\begin{array}{l}\text { New learning/experience/ } \\
\text { knowledge }\end{array}$ & & & & & & & & & $\mathrm{x}$ & $\mathrm{x}$ & $\mathrm{x}$ & & & & & & & & & & \\
\hline New quality/benefits & $\mathrm{x}$ & & & & & $\mathrm{x}$ & & & & & & & & & & & & & & & $\mathrm{x}$ \\
\hline
\end{tabular}

1. Cooper (1979)

2. Lawton \& Parasuraman (1980)

3. More (1982)

4. Maidique \& Zirger (1984)

5. Yoon \& Lilien (1985)

6. Cooper \& de Brentani (1991)

7. Kleinschmidt \& Cooper (1991)

8. Lee \& Na (1994)

9. Ali, Krapfel, \& LaBahn (1995)

10. Atuahene-Gima (1995)

11. Green, Gavin, \& Aiman-Smith (1995)

12. Olson, Walker \& Ruekert (1995)

13. Mishra, Kim, \& Lee (1996)

14. Souder \& Song (1997)

15. Schmidt \& Calantone (1998)

16. Colarelli O'Connor (1998)

17. Song \& Montoya-Weiss (1998)

18. Veryzer (1998)

19. Goldenberg, Lehman, \& Mazursky (1999)

20. Kessler \& Chakrabarti (1999)

21. Chandy \& Tellis (2000)

factors, (see Table 3). We thus maintain that product innovativeness is a measure of the potential discontinuity a product (process or service) can generate in the marketing and/or technological process. From a macro perspective, 'innovativeness' is the capacity of a new innovation to create a paradigm shift in the science and technology and/or market structure in an industry. From a micro perspective, 'innovativeness' is the capacity of a new innovation to influence the firm's existing marketing resources, technological resources, skills, knowledge, capabilities, or strat- egy. In the next section we will demonstrate how many researchers have labeled varying degrees of product innovativeness as different typologies.

First, it must be emphasized that product innovativeness does not equate to firm innovativeness. Firm or organizational innovativeness has been defined as the propensity for a firm to innovate or develop new products [16]. It has also been defined as the propensity for a firm to adopt innovations $[13,48]$. In either case, the innovativeness of a product that a firm markets or adopts is not a measure of organiza- 
Summary of constructs and factors in empirical research

\begin{tabular}{|c|c|c|c|c|c|c|c|c|c|}
\hline Author & Construct name & Factors & $\begin{array}{l}\text { \# of } \\
\text { items }\end{array}$ & $\begin{array}{l}\text { Alpha } \\
\text { or R }\end{array}$ & $\begin{array}{l}\text { Variance } \\
\text { explained }\end{array}$ & Scale & Categories & $\begin{array}{l}\text { \# of } \\
\text { products/ } \\
\text { projects }\end{array}$ & $\begin{array}{l}\text { Dependent } \\
\text { variable }\end{array}$ \\
\hline \multirow[t]{3}{*}{ Cooper (1979) } & \multirow[t]{3}{*}{ Product innovativeness } & Newness to the firm & 8 & \multirow[t]{3}{*}{ NR } & $10.10 \%$ & $\begin{array}{l}0-10 \\
\text { Likert }\end{array}$ & \multirow[t]{3}{*}{ Continuum } & \multirow[t]{3}{*}{195} & \multirow[t]{3}{*}{$\begin{array}{l}\text { New product } \\
\text { success }\end{array}$} \\
\hline & & $\begin{array}{l}\text { Product uniqueness } \\
\text { (Pioneer) }\end{array}$ & 6 & & $2.20 \%$ & $\begin{array}{l}0-10 \\
\text { Likert }\end{array}$ & & & \\
\hline & & $\begin{array}{l}\text { Product uniqueness/ } \\
\text { superiority }\end{array}$ & 3 & & $9.00 \%$ & $\begin{array}{l}0-10 \\
\text { Likert }\end{array}$ & & & \\
\hline \multirow[t]{2}{*}{$\begin{array}{l}\text { Lawton \& Parasuraman } \\
\text { (1980) }\end{array}$} & \multirow[t]{2}{*}{ Product innovativeness } & $\begin{array}{l}\text { Change in } \\
\text { behavioral patterns }\end{array}$ & 1 & \multirow[t]{2}{*}{ NR } & & $\begin{array}{l}1-7 \\
\text { Likert }\end{array}$ & $\begin{array}{l}\text { High/Medium/ } \\
\text { Low }\end{array}$ & \multirow[t]{2}{*}{107} & \multirow[t]{2}{*}{$\begin{array}{l}\text { Adoption of mktg } \\
\text { concept }\end{array}$} \\
\hline & & Product newness & 1 & & & $\begin{array}{l}1-7 \\
\text { Likert }\end{array}$ & $\begin{array}{l}\text { High/Medium/ } \\
\text { Low }\end{array}$ & & \\
\hline \multirow[t]{4}{*}{ More (1982) } & Marketing task similarity & & 10 & NR & & NR & Continuum & 43 & $\begin{array}{l}\text { Accept/reject } \\
\text { decision }\end{array}$ \\
\hline & Production complexity & & 5 & NR & & NR & & & \\
\hline & Distribution difficulty & & 5 & NR & & NR & & & \\
\hline & Development complexity & & 5 & NR & & NR & & & \\
\hline \multirow[t]{2}{*}{$\begin{array}{l}\text { Maidique \& Zirger } \\
\text { (1984) }\end{array}$} & Degree of technical content & & NR & NR & & NR & $\begin{array}{l}\text { Radical } \\
\text { breakthrough/ } \\
\text { significant } \\
\text { technical } \\
\text { change/ } \\
\text { incremental } \\
\text { change }\end{array}$ & $\begin{array}{l}\text { Survey I } \mathrm{n}= \\
78 \text { Survey II n } \\
=58\end{array}$ & Success/failure \\
\hline & Innovation type & & - & - & & NR & True/adoption & & \\
\hline Yoon \& Lilien (1985) & Product type & & - & - & & NR & $\begin{array}{l}\text { Original new } \\
\text { products/ } \\
\text { reformulated } \\
\text { new products }\end{array}$ & 112 & $\begin{array}{l}\text { New product } \\
\text { performance }\end{array}$ \\
\hline \multirow[t]{5}{*}{$\begin{array}{l}\text { Cooper \& de Brentani } \\
\text { (1991) }\end{array}$} & Synergy & & 7 & 0.837 & & $\begin{array}{l}1-7 \\
\text { Likert }\end{array}$ & Continuum & 106 & $\begin{array}{l}\text { New service } \\
\text { success }\end{array}$ \\
\hline & Newness to the firm & & 7 & 0.724 & & $\begin{array}{l}1-7 \\
\text { Likert }\end{array}$ & & & \\
\hline & Innovativeness of service product & & 3 & 0.71 & & $\begin{array}{l}1-7 \\
\text { Likert }\end{array}$ & & & \\
\hline & Product uniqueness and superiority & & 6 & 0.75 & & $\begin{array}{l}1-7 \\
\text { Likert }\end{array}$ & & & \\
\hline & Product/market fit & & 3 & 0.712 & & $\begin{array}{l}1-7 \\
\text { Likert }\end{array}$ & & & \\
\hline $\begin{array}{l}\text { Kleinschmidt \& Cooper } \\
\text { (1991) }\end{array}$ & Product innovativeness & & 6 & NR & & NR & $\begin{array}{l}\text { Highly/ } \\
\text { moderately/low } \\
\text { innovativeness }\end{array}$ & 195 & $\begin{array}{l}\text { New product } \\
\text { performance }\end{array}$ \\
\hline McDonough (1993) & Product type & & - & - & & & Routine/radical & 32 & $\begin{array}{l}\text { New product } \\
\text { development } \\
\text { speed }\end{array}$ \\
\hline
\end{tabular}


Table 3

Summary of constructs and factors in empirical research (cont.)

\begin{tabular}{|c|c|c|c|c|c|c|c|c|c|}
\hline Author & Construct name & Factors & $\begin{array}{l}\text { \# of } \\
\text { items }\end{array}$ & $\begin{array}{l}\text { Alpha } \\
\text { or } R\end{array}$ & $\begin{array}{l}\text { Variance } \\
\text { explained }\end{array}$ & Scale & Categories & $\begin{array}{l}\text { \# of } \\
\text { products/ } \\
\text { projects }\end{array}$ & $\begin{array}{l}\text { Dependent } \\
\text { variable }\end{array}$ \\
\hline Lee \& Na (1994) & Technical innovativeness of product & & 1 & - & & $\begin{array}{l}1-5 \\
\text { Likert }\end{array}$ & $\begin{array}{l}\text { Incrementally } \\
\text { improving/ } \\
\text { radical }\end{array}$ & 75 & $\begin{array}{l}\text { Technical } \\
\text { performance }\end{array}$ \\
\hline \multirow[t]{2}{*}{$\begin{array}{l}\text { Ali, Krapfel, \& LaBahn } \\
\text { (1995) }\end{array}$} & Product innovativeness & & 3 & 0.77 & & $\begin{array}{l}1-7 \\
\text { Likert }\end{array}$ & Continuum & 73 & Cycle time \\
\hline & Technical content & & 3 & 0.82 & & $\begin{array}{l}1-7 \\
\text { Likert }\end{array}$ & & & \\
\hline \multirow[t]{4}{*}{$\begin{array}{l}\text { Green, Gavin, \& } \\
\quad \text { Aiman-Smith (1995) }\end{array}$} & Radicalness of innovation & $\begin{array}{l}\text { Technical } \\
\text { uncertainty }\end{array}$ & 6 & & $3 \%$ & $1-7$ & Radical & 213 & $\begin{array}{l}\text { None-factor } \\
\text { analysis }\end{array}$ \\
\hline & & $\begin{array}{l}\text { Technical } \\
\text { inexperience }\end{array}$ & 3 & & $18 \%$ & $\begin{array}{l}1-7 \\
\text { Likert }\end{array}$ & & & \\
\hline & & Technology cost & 3 & & $11 \%$ & $\begin{array}{l}1-7 \\
\text { Likert }\end{array}$ & & & \\
\hline & & Business experience & 4 & & $61 \%$ & $\begin{array}{l}1-7 \\
\text { Likert }\end{array}$ & & & \\
\hline \multirow[t]{2}{*}{ Atuahene-Gima (1995) } & Product newness & $\begin{array}{l}\text { Newness to } \\
\text { customers }\end{array}$ & 6 & 0.78 & & & $\begin{array}{l}\text { Radical/ } \\
\text { Incremental }\end{array}$ & 119 Radical & $\begin{array}{l}\text { New product } \\
\text { performance }\end{array}$ \\
\hline & & Newness to firm & 1 & & & & & & 103 Incremental \\
\hline $\begin{array}{r}\text { Olson, Walker \& } \\
\text { Ruekert (1995) }\end{array}$ & Product innovativeness & Newness of product & 5 & 0.81 & NR & $1-5$ & $\begin{array}{l}\text { Radical/ } \\
\text { incremental }\end{array}$ & 45 & $\begin{array}{l}\text { Product and } \\
\text { financial } \\
\text { outcomes } \\
\text { efficiency } \\
\text { outcomes } \\
\text { psychosocial } \\
\text { outcomes }\end{array}$ \\
\hline \multirow[t]{4}{*}{$\begin{array}{l}\text { Mishra, Kim \& Lee } \\
\quad \text { (1996) }\end{array}$} & General characteristics & $\begin{array}{l}\text { Product } \\
\text { innovativeness }\end{array}$ & 1 & $r=0.675$ & & $\begin{array}{l}0-10 \\
\text { Likert }\end{array}$ & Continuum & 144 & $\begin{array}{l}\text { New product } \\
\text { success }\end{array}$ \\
\hline & & $\begin{array}{l}\text { Customization of } \\
\text { the product }\end{array}$ & 1 & $\mathrm{r}=0.629$ & & & & & \\
\hline & & Technology content & 1 & $\begin{array}{l}\mathrm{r}=0.621 \\
\text { correlation with } \mathrm{DV}\end{array}$ & & & & & \\
\hline & Newness to the firm & & 8 & NR & & $\begin{array}{l}0-10 \\
\text { Likert }\end{array}$ & Continuum & & \\
\hline Souder \& Song (1997) & Radicalness & & 3 & 0.74 & & $\begin{array}{l}1-5 \\
\text { Likert }\end{array}$ & Continuum & 156 & $\begin{array}{l}\text { New product } \\
\text { success }\end{array}$ \\
\hline $\begin{array}{l}\text { Schmidt \& Calantone } \\
\quad \text { (1998) }\end{array}$ & Product innovativeness & & - & - & & $\begin{array}{l}\text { High/ } \\
\text { low }\end{array}$ & $\begin{array}{l}\text { Innovative/ } \\
\text { incremental }\end{array}$ & 161 & $\begin{array}{l}\text { Likelihood of } \\
\text { failure/self- } \\
\text { reported } \\
\text { commitment/go/ } \\
\text { stop decision }\end{array}$ \\
\hline \multirow{2}{*}{$\begin{array}{l}\text { Colarelli O’Connor } \\
\text { (1998) }\end{array}$} & Source of technology & & 5 & NR & & & Discontinuous & 9 & Market learning \\
\hline & Nature of market needs & & 4 & NR & & & & & \\
\hline
\end{tabular}


Table 3

Summary of constructs and factors in empirical research (cont.)

\begin{tabular}{|c|c|c|c|c|c|c|c|c|c|}
\hline Author & Construct name & Factors & $\begin{array}{l}\text { \# of } \\
\text { items }\end{array}$ & $\begin{array}{l}\text { Alpha } \\
\text { or R }\end{array}$ & $\begin{array}{l}\text { Variance } \\
\text { explained }\end{array}$ & Scale & Categories & $\begin{array}{l}\text { \# of } \\
\text { products/ } \\
\text { projects }\end{array}$ & $\begin{array}{l}\text { Dependent } \\
\text { variable }\end{array}$ \\
\hline $\begin{array}{l}\text { Song \& Montoya- } \\
\text { Weiss (1998) }\end{array}$ & Product innovativeness & & NR & NR & & & $\begin{array}{l}\text { Really new/ } \\
\text { incremental }\end{array}$ & $\begin{array}{l}163 \text { Really } \\
\text { new/169 } \\
\text { incremental }\end{array}$ & $\begin{array}{l}\text { New product } \\
\text { success }\end{array}$ \\
\hline \multirow[t]{3}{*}{ Veryzer (1998) } & \multirow[t]{3}{*}{ Discontinuity index } & $\begin{array}{l}\text { Discontinuity of } \\
\text { product benefits }\end{array}$ & NR & & NR & NR & $\begin{array}{l}\text { High/medium/ } \\
\text { low }\end{array}$ & 7 & $\begin{array}{l}\text { Customer input/ } \\
\text { customer } \\
\text { evaluation }\end{array}$ \\
\hline & & $\begin{array}{l}\text { Discontinuity of } \\
\text { technological } \\
\text { capabilities }\end{array}$ & NR & & NR & NR & & & \\
\hline & & $\begin{array}{l}\text { Discontinuity of } \\
\text { consumption } \\
\text { patterns }\end{array}$ & NR & & NR & NR & & & \\
\hline \multirow[t]{3}{*}{$\begin{array}{l}\text { Goldenberg, Lehmann } \\
\text { \& Mazursky(1999) }\end{array}$} & \multirow[t]{3}{*}{ Newness } & $\begin{array}{l}\text { Newness to the } \\
\text { market }\end{array}$ & 1 & & - & $0-2$ & $\begin{array}{l}\text { High/moderate/ } \\
\text { low }\end{array}$ & 197 & $\begin{array}{l}\text { New product } \\
\text { success }\end{array}$ \\
\hline & & Newness to the firm & 1 & & - & $0-1$ & New/not new & & \\
\hline & & $\begin{array}{l}\text { Newness of the } \\
\text { technology }\end{array}$ & 1 & & - & $0-2$ & $\begin{array}{l}\text { High/moderate/ } \\
\text { low }\end{array}$ & & \\
\hline $\begin{array}{l}\text { Kessler \& Chakrabarti } \\
\text { (1999) }\end{array}$ & Product radicalness & & 2 & NR & & $1-5$ & $\begin{array}{l}\text { Radical/ } \\
\text { incremental }\end{array}$ & $\begin{array}{l}42 \text { radical } 33 \\
\text { incremental }\end{array}$ & Innovation speed \\
\hline \multirow[t]{2}{*}{$\begin{array}{l}\text { Chandy \& Tellis } \\
\text { (2000) }\end{array}$} & \multirow[t]{2}{*}{$\begin{array}{l}\text { Radical product } \\
\text { innovation }\end{array}$} & $\begin{array}{l}\text { Technology } \\
\text { difference }\end{array}$ & 1 & & - & $1-9$ & Continuum & 64 & $\begin{array}{l}\text { Radical product } \\
\text { innovation }\end{array}$ \\
\hline & & Customer benefits & 1 & & - & $1-9$ & & & \\
\hline
\end{tabular}


tional innovativeness. Many firms have taken an innovation strategy of imitating and improving upon existing products or technologies. This approach is described by the 'analyzer' strategy suggested by Miles and Snow [39]. This type of firm is very successful at improving upon existing product designs. Microsoft is a classic example of this type of strategy. Even successful analyzers, including Microsoft, are often viewed by their competitors as great imitators and not highly innovative. Thus, a highly innovative product does not automatically imply highly innovative firms.

\section{Innovation typology comparisons}

There is no question that not all innovations are the same. Accordingly, they are frequently classified into typologies as a means of identifying their innovative characteristics or degree of innovativeness. It has been theorized and empirically tested that the varying degrees of newness and the discontinuities resulting from highly innovative innovations will change the important factors in the NPD process [18, 47,54]. This contingency approach to the NPD process has resulted in researchers devising ad hoc typologies to label degrees of innovativeness. A review of the literature reveals the following categorizations:

- eight categories-reformulated/new parts/remerchandising/new improvements/new products/new user/ new market/new customers [29];

- five categories-systematic/major/minor/incremental/ unrecorded [18];

- tetra-categorization -incremental/modular/architectural/radical [27], niche creation/architectural/regular/ revolutionary [1], incremental/evolutionary market/ evolutionary technical/radical [42], incremental/ market breakthrough/technological breakthrough/ radical [7], incremental/architectural/fusion/ breakthrough [57];

- triadic categorization-low innovativeness/moderate innovativeness/high innovativeness [31], incremental/ new generation/radically new [62] and,

- dichotomous categorization-discontinuous/continuous [3,47], instrumental/ultimate [23], variations/reorientations [43], true/adoption [37], original/reformulated [64], innovations/reinnovations [49], radical/ routine [38], evolutionary/revolutionary [59], sustaining/disruptive [9], really new/incremental [50, 54], breakthrough/incremental [46], and radical/incremental $[5,18,4,30,35,52,56]$.

This abundance of typologies has resulted in the same name being used for different types of innovations and the same innovation being classified under different typologies. The following review of four different classifications by four groups of researchers will demonstrate this point.

Utterback [59] provides the following definition of a discontinuous or radical innovation: "By discontinuous change or radical innovation, I mean change that sweeps away much of a firm's existing investment in technical skills and knowledge, designs, production technique, plant and equipment" [p. 200]. From Utterback's perspective, dislocation or discontinuity at the firm level or in the industry accompanies the introduction of radical innovations. Continuous (incremental) innovations give way to standardization and status quo within the firm or industry.

Rothwell and Gardiner [49] focus on technological discontinuity, by emphasizing 'reinnovations' or improvements on existing innovations. Their dichotomy of 'innovations' and 'reinnovations' leads to several subcategories. 'Innovations' are radically new inventions establishing landmark new products, and as such, create new industries. 'Reinnovations' dominate much of the contemporary "real" industrial world. They result in existing technology improving upon existing product design (incremental), new technology improving existing products (generational), existing technology creating new products (new mark products), improved materials improving existing products (improvements), and new technology improving subsystems of existing products (minor details).

Another viewpoint, Kleinschmidt and Cooper's [31] study of 195 new products, leads to a triad categorization. Kleinschmidt and Cooper's typology distinguishes between 'high', 'moderate', and 'low' innovativeness. Highly innovative products include new to the world products and new to the firm lines, which are also new to the market. Moderately innovative products consist of less innovative new lines to the firm and new products to the existing product line. Low innovative products include modifications, cost reductions, and repositioning.

A fourth perspective, Abernathy and Clark's [1] matrix categorization focuses on competitive significance by mapping technology competence against market environments. The four resulting categories for innovations are 'niche creation', 'architectural', 'regular' and 'revolutionary'. In niche creations, stable and well-specified existing technology is refined, improved, or changed to support a new market position. These refinements build on established technical competence and improve product applicability in emerging market segments. Architectural innovations forge new market linkages with new technology through the creation of new industries or the reformation of existing ones. They set the future architecture of the industry. Regular innovations build on established technical and production competences targeted to existing markets and customers. They often involve incremental improvements in process technology. Revolutionary innovations disrupt and obsolete technical and production competence but target existing markets and customers.

A couple of examples will demonstrate how just these four different classification approaches can lead to different labeling of the same innovation. A classic example is the typewriter. Utterback [59] writes, "Discontinuities were observed between the periods of the manual typewriter, electrics, dedicated work 
processors, and personal computers. Of the large manual typewriter firms of the early twentieth century, none were successful in jumping onto the bandwagon of the electric typewriter; it was IBM, an outsider that developed both the product and its market" [p. 201]. Based on this scenario, Utterback would designate the electric typewriter as a radical innovation because the new technology brought about industrial discontinuity and new competitors.

The Rothwell and Gardiner typology identified an 'incremental' design as adding radical new features to improve upon an existing innovation. Thus, Rothwell and Gardiner would label the electrical technology advancement from manual to electric typewriters as an incremental innovation. Kleinschmidt and Cooper would label the typewriter technology evolution a moderate innovation and Abernathy and Clark would call it a revolutionary innovation.

Another example is the Canon laser photocopier which produced digital signals that could be electronically digitally processed, stored or transmitted simultaneously to a number of distant slave printers. The analog system of its conventional predecessors were unable to network. The new technology was the application of a laser and electronic information processing step inserted between the original optical and print systems. The digital processing subsystem allowed the production of a technologically new laser digital copier. Utterback would label the movement from analog to digital technology a market broadening, competence enhancing, radical innovation. Yet for Rothwell and Gardiner, radical technology embedded in a reinnovation does not constitute a radical innovation, instead just a redesign on an 'innovation'. Thus, they would label this innovation an incremental innovation with a subassembly change. Kleinschmidt and Cooper would label it a moderate innovation, and to Abernathy and Clark the copier technology evolution is a regular innovation.

As these two examples demonstrate, the same innovation can be labeled on either ends of the scale of innovativeness depending on the researcher. This ambiguity in classification schema makes it impractical, if not impossible, to accurately compare research studies. With these types of terminology irregularities, it is impossible to accumulate knowledge regarding innovation types and how their varying degrees of newness alter the NPD process. The next section will review how inconsistencies also plague the operationalization of product innovativeness in empirical literature.

\section{Empirical literature compared}

As the previous review demonstrated, ad hoc categorizations of innovations into degrees of innovativeness has led to inconsistencies in labeling innovation types. This becomes evident by examining how product innovativeness has been operationalized in the empirical literature. Table 1 lists 15 constructs identified and Appendix A lists 51 distinct measures from the extant NPD literature.
A review of the literature reveals incongruence in the operationalization of product (process/service) innovativeness at four different levels: [1] modeling from a macro or microperspective, [2] modeling marketing and/or technological discontinuities, [3] modeling a single dimensional or multifactorial construct, and [4] modeling innovativeness as a categorical or continuous variable. A single theme, however, does underlie all these classifications of innovations: innovativeness is a measure of discontinuity in the status quo in marketing factors and/or technology factors. This section focuses on the studies that have reached empirical conclusions about the moderating or mediating effects of product innovativeness. We also include studies where product innovativeness is modeled as a dependent variable. The unit of analysis considered is the project level for products, processes, and services developed for the purpose of outside-the-firm commercialization. We will not review studies that have focused on firm innovativeness.

\subsection{Macro/microperspective}

The measurements utilized in the empirical analyses reviewed can be broken into two frameworks; (a) a macrolevel where the concern is measuring how the characteristics of product innovation is new to the world, the market, or an industry [4,35,37,40,50,64], and (b) a microlevel where product innovativeness is identified as new to the firm or the customer [41]. In the literature included in this comparison, researchers most frequently used both a macro and a microperspective in modeling the construct $[2,10,11$, $12,31,20,21,45]$. The distinction between macro and micro perspectives is important as it identifies newness of an innovation to whom and from whose perspective. Comparisons across research findings become more relevant with this delineated perspective.

From a macro perspective, innovativeness is evaluated based on factors exogenous to the firm, such as familiarity of the innovation to the world and industry or creation of new competitors from the introduction of new innovations. Macro discontinuities are felt worldwide, industry-wide or market-wide. The discontinuities that result are not dependent upon a firm's strategy or structure, its competencies, its knowledge base or its availability of resources.

It must take a highly radically innovative product to cause discontinuity in the world. Few products have the inertial forces to accomplish this feat, although they do exist, for example, the Watt steam engine (circa 1769), the telegraph (circa 1840), and the World Wide Web (circa 1980). The steam engine drove the industrial revolution and the World Wide Web is a major driving force in the informational revolution. Discontinuities to an industry are more easily identifiable. The Sony Walkman created a new market for mobile entertainment and a new industry for miniaturized electronics. The Apple computer instigated new uses, new customers and new distribution channels for home computers. Innovations causing discontinuities in the 
marketplace are ubiquitous; examples include, the compact disc, antilock brakes, sport utility vehicles, polartec fleece, homogenization procedures, nylon material, and the ATM.

The microperspective views product innovativeness as new to the firm or new to the firm's customer [11,12,31,41]. Discontinuities can occur in a firm's marketing or R\&D strategy, in a firm's supplier or distribution chains, or in its sales approach. However, a product's innovativeness is contingent upon the firm's capabilities and competencies. For a electronics manufacturer such as IBM to begin to manufacture and market electric automobiles would be a disruptive and discontinuance endeavor. Yet, for General Motors to design and market the same electric vehicle would not be considered discontinuous. Similarly, the same product may be defined with varying degrees of innovativeness by a firm's customers.

\subsection{Marketing/technological discontinuities}

Technological innovations have two 'forces' from which discontinuities may originate -from a marketing direction or from a technological direction. Product innovation may require new marketplaces to evolve, and/or new marketing skills for the firm. Similarly, product innovations may require a paradigm shift in the state of science or technology embedded in a product, new R\&D resources, and/or new production processes for a firm. Some products, of course, may require discontinuities in both marketplace and technological factors. Studies reviewed cover all three of these scenarios; marketplace discontinuity [4,33,50,64], technological discontinuity [10,37], and both types of discontinuities $[2,11,12,21,31,35,40,41,45]$.

\subsection{Single/multiple factors}

'Product innovativeness' was most often modeled as a multidimensional reflective variable as opposed to a single dimensional variable. The single factor operationalization varied from measuring one item up to nine items. Even from a single dimension viewpoint there was no consistency in taking a macro or microperspective or both and in taking a marketing or technological perspective or both. All constructs reported in the studies take these perceptions in different combinations, that is, a macroperspective of marketing forces, microperspective of technological forces, and so forth.

The multifactorial operationalization of product innovativeness had greater consensus among the studies. The most commonly employed multidimensional construct used both macro and micromeasures to determine discontinuities in both market and technology issues. These multidimensional studies comprised on average three factors. The construct 'newness to the firm' was used in half of these studies. Of the 21 differently labeled factors identified by researchers through factor analysis (see Table 3), 12 unique factors were
Table 4

Factors used to model product innovation/innovativeness

\begin{tabular}{ll}
\hline Construct & Study* \\
\hline - Product newness to the firm & $1,2,3,5,8$ \\
- Product uniqueness (1st to market) & 1 \\
- Product uniqueness/superiority & 1,6 \\
- Change in behavioral patterns & 2,7 \\
- Product newness to customers & 3 \\
- Technical uncertainty & 4 \\
- Technical inexperience (newness) & $4,7,8,9$ \\
- Technology cost & 4 \\
- Business experience & 4 \\
- Product innovativeness & 6 \\
- Discontinuity of product benefits & 7 \\
- Newness to the market & 8 \\
\hline
\end{tabular}

\footnotetext{
* Some studies found more than one factor.

1. Cooper (1979)

2. Lawton \& Parasuraman (1980)

3. Atuahene-Gima (1995)

4. Green, Gavin, \& Aiman-Smith (1995)

5. Olson, Walker \& Ruekert (1995)

6. Mishra, Kim, \& Lee (1996)

7. Veryzer (1998)

8. Goldenberg, Lehman, \& Mazursky (1999)

9. Chandy \& Tellis (2000)
}

identified (Table 4). Of course, only a test of discriminant validity can verify their distinctiveness.

\subsection{Categorical/continuous measures}

The fourth level showing lack of consensus was in using categorical or continuous measures. Those researchers using categorical measures most frequently summed the scales and split the sample into groupings of high/low/moderate innovativeness or some similar categorization [31]. Using this method does not allow for external validity as the split in the data is dependent upon the sample of an often-limited population. Nor does it allow the findings from one study on radical innovations to be compared to another study on radical innovations. For example, one firm may have a marketing strategy which focuses on incremental improvements on products. Any divergence from this strategy would result in a radical innovation to that firm (recall our IBM/General Motors example). However, that product may not be a radical innovation to the next firm. Thus, findings for one study cannot be compared to another study as the degree of innovativeness is a factor of the newness of the innovation to a particular firm.

'Continuous measures' used a set of 1-5 or 1-7 Likert scale items (ordinal measures) and then often used the summated measures as an independent or dependent variable in the model being evaluated. Overall no consistency exists in the operationalization of innovativeness in terms of categorical or continuous measurement. 


\subsection{Consensus on discontinuities}

Measuring product innovativeness based on marketing and/or technological discontinuities was the single level of consensus in the literature reviewed. Highly innovative products were seen to have shallow existing market or technical knowledge bases, whereas low-level innovative products did not require new product marketing or technological knowledge.

This review of the literature clearly demonstrates that there are few consistencies in the new product development literature for operationalizing 'product innovativeness'. As previously noted, this lack of consistency has resulted in little accumulated knowledge beyond an ad hoc level concerning the effects of innovativeness of a product on the NPD process. Many studies result in 'new' findings that are just another way of phrasing the same issue addressed in another study. In order to propose a method of operationalizing product innovativeness, it is first necessary to build a framework for identifying different product innovation types based on their discontinuities. In the next section, we will propose such a framework and then suggest a means of operationalizing 'product innovativeness' which will provide consistency and convergence in modeling this construct.

\section{A typogoly for identifying technological innovations}

Recent new product development literature has elucidated the importance of categorizing innovations into radical and incremental $[7,38,54,61]$. However, as previously demonstrated, 'radical' and 'incremental' can be defined in numerous fashions and is dependent upon from whose perspective innovativeness is being evaluated. "At present, the literature does not contain a measure of the radicalness of innovations, yet this is a critical variable in the field of innovation and new products" [7 p. 1]. It is our goal in this section to provide a typology for classifying innovations based upon the extant literature. We will provide answers to our questions posed in the introduction; "What is the difference between a radical, really new and discontinuous innovation?' and 'What is the difference between an incremental and imitative innovation?' It is important to emphasize that this typology is relative -relative to the firm. What one firm identifies as a really new innovation, can be labeled as an incremental innovation by another firm. The important fact remains that the procedures for developing really new innovations are relevant to the one firm and incremental innovation development procedures are relevant to the other firm -even though they are both developing the same innovation. The end results for the firms will be the same, the process of reaching this result will differ significantly. In no way should this confuse the identification process for determining the 'innovativeness' of a new product.

The new product literature has mainly used a dichoto- mous classification for identifying innovation type. We believe that this dichotomy is too simplistic. Radical innovations are rare in occurrence. It has been suggested that only $10 \%$ of all new innovations fall into the category of radical innovations [6,22,49,63]. Although Rothwell and Gardiner have suggested that incremental innovations cover the $90 \%$ of the remaining cases, we do not agree with this conclusion. We maintain that a third category is necessary in classifying innovations. We will use 'really new' to identify this third categorization.

Looking at the two levels previously discussed, macro versus micro and marketing versus technology perspectives, a means for identifying innovation types using Boolean logic can be devised (see Appendix B). This logic provides unambiguous labels for 'radical', 'really new', and 'incremental' innovations. Radical innovations are innovations that cause marketing and technological discontinuities on both a macro and microlevel. Incremental innovations occur only at a microlevel and cause either a marketing or technological discontinuity but not both. Really new innovations cover the combinations in between these two extremes.

Based on this classification schema, there are eight combinations of innovation types possible. It is impossible to have an innovation that is discontinuous on a macro level and not on a microlevel, thus, several combinations are eliminated. Radical innovations represent $1 / 8$ of these possibilities or $12.5 \%$ (Table 5). Really new innovations represent 4 of the 8 combinations or $50 \%$ of all types of innovations, and incremental innovations represent $37.5 \%$ of technological innovations. Our splits are in line with the Maidique and Zirger [37] breakdown which categorized $16.7 \%$ of all innovations to be 'radical breakthrough' products, $58.3 \%$ as 'significant technical change' products, and $25 \%$ as 'incremental change' products. Kleinschmidt \& Cooper [31] provided breakdowns of $30 \%$ to 'highly innovative' products, $47 \%$ to 'moderately innovative' products and $23 \%$ to 'low innovativeness'. Additionally, Griffin [22] found similar results in a more recent study (breakdowns of $10 \%, 42 \% \& 48 \%$ ). The important distinction is that in a random sample, radical innovations are rare and should be not account for more than $20 \%$ of the sample, likewise, incremental innovations should account for no less than $20 \%$ of the sample. In this section we describe the characteristics of each of these types of innovations.

\subsection{Radical innovations}

Radical innovations have been defined as innovations that embody a new technology that results in a new market infrastructure $[10,54]$. We have also maintained that radical innovation introductions result in discontinuities on both a macro and micro level. An innovation that causes discontinuity on a world, industry or market level will automatically cause discontinuities on the firm and customer level. If a new industry results from a radical innovation (i.e., the 
Table 5

Typology for identifying innovations

\begin{tabular}{|c|c|c|c|}
\hline Innovation type & Level & Present & Examples \\
\hline Radical innovation & $\begin{array}{l}\text { - Macro } \\
\text { - Marketing discontinuity } \\
\text { - Technology discontinuity } \\
\text { - Micro } \\
\text { - Marketing discontinuity } \\
\text { - Technology discontinuity }\end{array}$ & $\begin{array}{l}X \\
X\end{array}$ & $\begin{array}{l}\text { - Steam engine } \\
\text { - Telegraph } \\
\text { - } \text { WWW }\end{array}$ \\
\hline Really new & $\begin{array}{l}\text { - Macro } \\
\text { - Marketing discontinuity } \\
\text { - Technology discontinuity } \\
\text { - Micro } \\
\text { - Marketing discontinuity } \\
\text { Technology discontinuity }\end{array}$ & $\begin{array}{l}X \\
X \\
X\end{array}$ & $\begin{array}{l}\text { - Canon laserjet } \\
\text { - Early fax machines } \\
\text { - Electron microscope }\end{array}$ \\
\hline Really new & $\begin{array}{l}\text { - Macro } \\
\text { - Marketing discontinuity } \\
\text { - Technology discontinuity } \\
\text { - Micro } \\
\text { - Marketing discontinuity } \\
\text { Technology discontinuity }\end{array}$ & $\begin{array}{l}X \\
X\end{array}$ & $\begin{array}{l}\text { - Sony walkman } \\
\text { - Early telephone }\end{array}$ \\
\hline Really new & $\begin{array}{l}\text { - Macro } \\
\text { - Marketing discontinuity } \\
\text { - Technology discontinuity } \\
\text { - Micro } \\
\text { - Marketing discontinuity } \\
\text { Technology discontinuity }\end{array}$ & $\mathrm{X}$ & $\begin{array}{l}\text { - Hummer } \\
\text { - Early commercial jetliner }\end{array}$ \\
\hline Really new & $\begin{array}{l}\text { - Macro } \\
\text { - Marketing discontinuity } \\
\text { - Technology discontinuity } \\
\text { - Micro } \\
\text { - Marketing discontinuity } \\
\text { - Technology discontinuity }\end{array}$ & X & - Diesel locomotive \\
\hline Incremental & $\begin{array}{l}\text { - Macro } \\
\text { - Marketing discontinuity } \\
\text { - Technology discontinuity } \\
\text { - Micro } \\
\text { - Marketing discontinuity } \\
\text { - Technology discontinuity }\end{array}$ & $\begin{array}{l}X \\
X\end{array}$ & $\begin{array}{l}\text { - Super sonic transport } \\
\text { - } \text { BMW-M5 }\end{array}$ \\
\hline Incremental & $\begin{array}{l}\text { - Macro } \\
\text { - Marketing discontinuity } \\
\text { - Technology discontinuity } \\
\text { - Micro } \\
\text { - Marketing discontinuity } \\
\text { Technology discontinuity }\end{array}$ & $X$ & - Digital automotive control systems \\
\hline Incremental & $\begin{array}{l}\text { - Macro } \\
\text { - Marketing discontinuity } \\
\text { - Mechnology discontinuity } \\
\text { - Micro } \\
\text { - Technoting discontinuity } \\
\text { Tiscontinuity }\end{array}$ & $\mathrm{X}$ & - "Health" foods \\
\hline
\end{tabular}

World Wide Web), new firms and new customers also emerge for that innovation.

Radical innovations often do not address a recognized demand but instead create a demand previously unrecognized by the consumer. This new demand cultivates new industries with new competitors, firms, distribution channels, and new marketing activities. In the late 1970s most households could not imagine a reason why they would need a home computer. Today a multibillion dollar market targets these exact customers. Radical new technology acts as the catalyst for the emergence of new markets and/or new industries.

A tool that can aid in the identification of radical innovations is the technology S-curve introduced by Foster [17]. The S-curve has been used to describe the origin and evolution of technologically discontinuous/radical innovations $[7,59,60]$. This theory suggests that technological product performance moves along an S-curve until technical limi- 


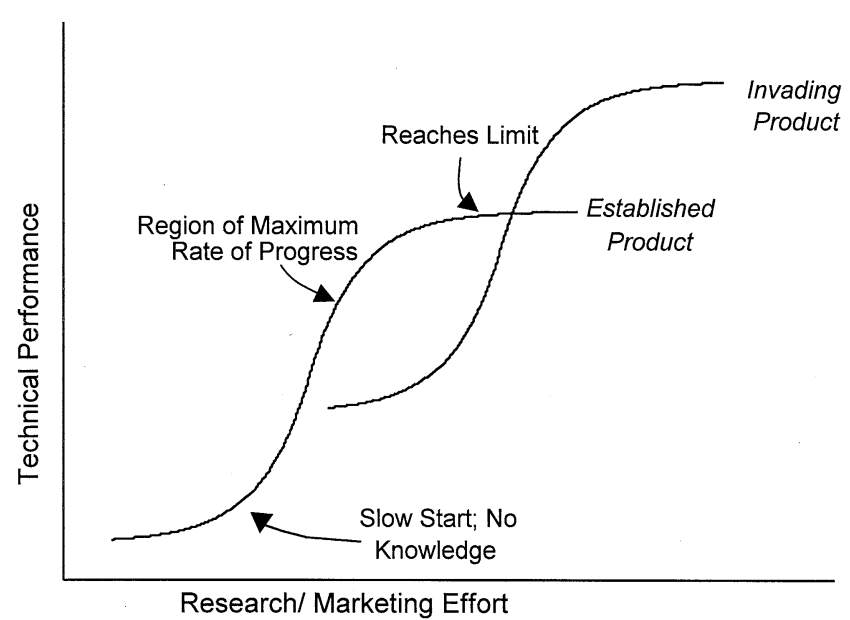

Fig. 1. Technology/Marketing S-Curve Phenomena (adapted from Foster 1986).

tations cause research effort, time, and/or resource inefficiencies to result in diminishing returns. New innovations replace the old technology and a new $\mathrm{S}$-curve is initiated (see Fig. 1). Foster characterized the technology evolution; "early in an R\&D program, knowledge bases need to be built, lines of inquiry must be drawn and tested and technical problems surfaced. Researchers need to investigate and discard unworkable approaches. Thus, until this knowledge has been acquired, the pace of progress toward technological limits is usually slow. But then it picks up, typically reaching a maximum when something like half the technical potential has been realized. At this point, the technology begins to be constrained by its limits, and the rate of performance improvement begins to slow" [17 p. 217].

Similar analogies can be made for proposing a market S-curve. Early in market formation, knowledge bases need to be built, lines of inquiry must be drawn and tested, and market-related issues surface. Marketers need to investigate and discard unworkable approaches (i.e., the World Wide Web marketplace at this time). New markets evolve that support the new technological innovation, new competitors enter the market, and new partners and distribution channels emerge to exploit the new technology. Thus, until this market know-how has been acquired, the pace of progress toward market limits may be slow. Diminishing returns are experienced when the market place becomes saturated with competitors and me-too products.

Thus, a radical innovation can be identified by the initiation of a new technology and new marketing S-curve. With this viewpoint it is easy to see that 'planning' for radical innovation requires understanding how to strategically plan for both the technological discontinuities and marketplace discontinuities for the global marketplace. Most firms are unable to alter the inertial forces driving the firm down a particular path, thus, to plan for major strategic changes based on macrolevel changes is unlikely. This is not to say that nimble innovative firms or even serendipity in more staid firms cannot drive radical innovations, but more to the point, because of their nature, radical innovations are rare.

Another test for radical innovations is to determine if the firm's internal marketing and technology S-curve has been impacted. Kusunoki [Kusunoki, 1997, 32] writes, “. . . besides technological capabilities, introducing radical product change to a market often requires a new set of organizational capabilities embedded in structures, communication channels, and information processing procedures of organizations, and it is usually quite difficult for established firms to adjust their organizational capabilities for developing innovative products" [p. 369]. A failure to find discontinuity in technology and marketing strategies within a firm, should automatically exclude the product from being considered radical. Finding a microlevel shift in the S-curves, is necessary but not sufficient criteria for radical innovativeness as it also is an indicator of really new innovations.

\subsection{Really new innovations}

Although they comprise the majority of innovations, it is surprising that the moderately innovative class of innovations that lie in between radical and incremental has had so little attention in the literature in the last twenty years. Kleinschmidt \& Cooper define moderately innovative products as "consisting of lines to the firm, but where the products were not as innovative (that is not new to the market) and new items in existing product lines for the firm" [p. 243]. We will term the moderately innovative product a 'really new' innovation. On a macro level, a really new product will result in a market discontinuity or a technological discontinuity but will not incorporate both. (If both do occur, it should be classified as a radical innovation, if no discontinuity occurs at the macro level, it should be classified as an incremental innovation.) On a microlevel any combination of marketing and/or technological discontinuity can occur in the firm. Really new innovations are easily identifiable by the criteria that a discontinuity must occur on either a marketing or technological macro basis in combination with a microlevel discontinuity. They can evolve into new product lines (e.g., Sony Walkman), product line extensions with new technology (e.g., Canon Laserjet), or new markets with existing technology (e.g., early fax machines).

Frequently 'really new' products are misclassified as 'radical innovations' and 'radical innovations' are misclassified as 'really new' products. A case in point is the recent research by Kessler \& Chakrabarti [30]. They empirically investigated the array of factors that affect speed of the innovation process. They sorted 75 projects into 'degree of change undertaken' identifying 33 incremental innovations and 42 radical innovations. Since less than $20 \%$ of innovations develop into radically new products, it is unlikely that these 42 innovations were 'radical'. Evaluating the innovation's technology and market S-curves is an easy test to determine the appropriate classification. 
Likewise the research by Atuahene-Gima [4] on market orientation uses 'degree of product newness' to classify 103 incremental innovations and 119 radical innovations. The groups were split into product improvements and line extensions (incremental innovations) and new product lines and new to the world products (radical innovations). As radical innovations do not occur more frequently than incremental innovations, Atuahene-Gima's 'radical' innovations may more likely have been really new products. New product lines rarely result in both new marketing and technical infrastructures. With this reclassification from radical innovation to really new product innovations, one must question whether the destructive radical innovation process is accelerated by concept clarity, champion presence, and colocations as reported in the Kessler \& Chakrabarti findings or is it the really new product innovation process that is sped to market by these factors?

Song \& Montoya-Weiss [54] classify really new innovations as "as an entirely new product category and/or production and delivery system. A really new product is one that: (1) relies on technology never used in the industry before; (2) has an impact on or causes significant changes in the whole industry; and (3) is the first of its kind and totally new to the market" (pg. 126). By this definition, it is likely that a portion of Song \& Montoya-Weiss' 163 really new innovations may have been radical innovations. (Their sample split was 163 really new innovations and 169 incremental innovations). This classification for radical and really new innovation now allows us to differentiate these two types of innovations from discontinuous innovations.

\subsection{Discontinuous innovations}

A discontinuous innovation may be either a radical innovation or really new innovation dependent upon at which level (macro/micro) and which S-curve(s) (marketing/technology/both) is affected by the introduction of the invention to the marketplace. Frequently discontinuous innovations refer to technological discontinuities $[10,58,61]$. Rice et al. [46] define discontinuous innovations as " 'game changers' which has potential (1) for a 5-10 times improvement in performance compared to existing products; (2) to create the basis for a $30-50 \%$ reduction in costs; or (3) to have new-to-the world performance features" (pg. 52). Rice et al. provide examples such as GE's digital X-ray, TI's digital light projector, GM's hybrid vehicle, IBM's silicon germanium devices and the Otis bi-directional elevator. These examples demonstrate new technologies that did not lead to discontinuity in the existing market infrastructures. The digital X-ray and the digital light projector are product line extensions. The hybrid vehicle, the IBM semiconductor, and the bi-directional elevator are new product lines. Thus, we contend that most examples of discontinuous innovations are really new innovations since only one of the S-curves is affected. A discontinuous innovation may indeed be a radical innovation if both S-curves are perturbed.

\subsection{Incremental innovations}

Incremental innovations can easily be defined as products that provide new features, benefits, or improvements to the existing technology in the existing market. "An incremental new product involves the adaptation, refinement, and enhancement of existing products and/or production and delivery systems" [54], p. 126]. Incremental innovations will occur only on a microperspective affecting either the marketing and/or technology S-curve(s). Incremental innovations will not result in macro discontinuities which are only seen in radical or really new innovations. "Incremental innovations are important on two main counts: first as a competitive weapon in a technologically mature market; and second, because streamlined procedures based on existing technology can help alert a business in good times to threats and opportunities associated with the shift to a new technological plateau" [28]. For many firms, incremental innovations are the lifeblood of the organization.

Incremental innovations evolve from the iterative nature of the process of innovation previously discussed. Rothwell and Gardiner [49] show that incremental innovations can occur at all stages of the new product development process. At the conceptualization stage, R\&D may use existing technology to improve an existing product design. At the mature stage of a product's life, line extensions may result in incremental innovations. Rothwell and Gardiner point out that a 'borrowed' technology from a different industry may be new to a different market. If it does not alter on a macrolevel either the technology or marketing S-curves or on a microlevel both curves, this borrowed technology would be considered an incremental innovation.

\subsection{Imitative innovations}

As previously noted, the difference between incremental and imitative innovations should be clarified. Grupp [24] provides a very succinct definition of imitative innovations. "Innovation occurs only in the first company to complete industrial R\&D which culminates in the launch of the first product on the markets. Rival innovations are designated imitations even if, in intracorporate term, very similar R\&D processes are only a short distance from one another chronologically. The imitator need not necessarily be aware of or be able to benefit from the first innovator. Imitations can thus be just as resource-intensive, especially $R \& D$ intensive, as the first innovation" [p. 20]. Because of their iterative nature, imitative products are frequently new to the firm, but not new to the market. Thus, imitative innovations usually have low technological innovativeness and low market innovativeness.

Imitative innovations should not be underrated. Innovative imitators can significantly alter the market direction. "If an innovator does not move quickly, and keep moving, the early imitators can play a major role in "remaking" or "creatively destroying" the market... Moreover, if they 


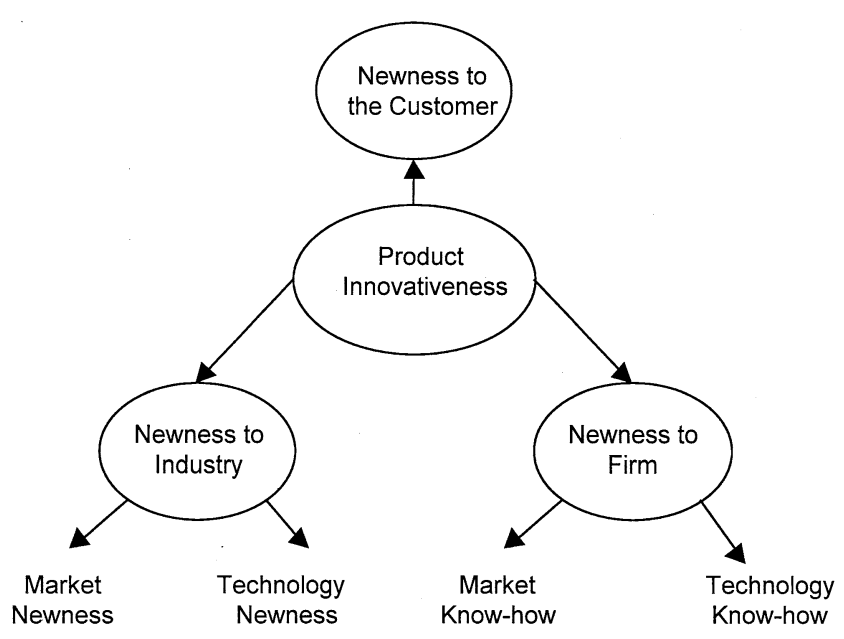

Fig. 2. Operationalization of innovativeness.

have more resources and already have a large market share, it is their imitative reactions that will have the most impact on changing the market and the rate of change and competitive dynamics in the market" [14] pg. 69]. Based on our typology, imitative innovations will most likely be incremental innovations, although on rare occasions they will be really new innovations.

Using items that measure product innovativeness on a macro and microlevel and on marketing and technological discontinuity, it is easy to classify highly innovative products as radical innovations, moderately innovative products as really new innovations and low innovativeness products as incremental innovations. As we have noted, other typologies have been utilized but we recognize these as just alternative variations of these three product types. Thus, in consensus with many researchers, we suggest that the labels 'radical', 'really new', and 'incremental' are appropriate classifications for signifying diminishing degrees of product innovativeness. Now that we have proposed a classification schema for product innovations, in the next section we will focus on providing a method of operationalizing product innovativeness in future empirical analyses.

\section{Operationalization of 'product innovativeness'}

We previously discussed how product innovativeness has been modeled in the extant literature (Tables 1 and 4). We also demonstrated how inconsistencies currently exist in these operationalizations. We, thus, propose an operationalization that may provide congruence to this construct beyond that obtained to date. As emphasized, product innovativeness must be evaluated upon two dimensions, a macro/micro and a marketing/technology discontinuity. This leads to modeling 'product innovativeness' as a second-order factor model. Fig. 2 provides a visual conceptualization for the following discussion.

Second-order factors are easily modeled in structural equation models and are not so easily represented in other modeling methodologies. We use the second-order model to facilitate the discussion that the construct 'innovativeness' is comprised of two distinctly different components that must both be represented in the measures in order to provide content validity. Radical innovations were previously identified as innovations that have discontinuities along both levels (macro/micro) and both sublevels (marketing/technology). Really new innovations are identified as having discontinuities along just a single level of the macro level (macromarketing or macrotechnology) but not both, and at the sublevel on any dimension-micromarketing and microtechnology. Incremental innovations have discontinuities just along the micro level. Failure to include measures that represent both levels of this construct will result in fatal content validity misrepresentation. Thus, regardless of the methodological techniques employed in an empirical study, the following discussion is valid for suggesting an operationalization method for the construct 'technological innovativeness' for NPD studies. Below, we elaborate on this multilevel factor and develop propositions for operationalizing this construct.

\subsection{First order factor}

At the first order level, the macro and micro perspectives are distinct from each other. The most important distinction to keep in mind is that on a macro level, discontinuities are exogenous to the firm. On either a macro or micro level, product innovativeness must embody a marketing or a technology discontinuity. We maintain that the higher the innovativeness in both factors, the greater the impact on product innovativeness. If the market discontinuity is low or the technological discontinuity is low, this leads to low product innovativeness. On the contrary, high discontinuity in both factors leads to high product innovativeness. The first factor level allows the split representation on the macro level -from an industry perspective, and on the micro level -from a firm perspective.

It may have been noted that we did not model 'newness to the world' or 'newness to the market'. 'Newness to the industry' automatically implies 'newness to the market' as the marketplace is a subset of the industry, thus, it does not need to be explicitly modeled. The distinction between the marketplace and an industry is that the industry is comprised of several different markets. For example the computer industry is made up of the mainframe market, the laptop market, the home computer market, and so forth. If an innovation is new to the industry, it is new to the marketplace or marketspace.

'New to the world' has also not been modeled in our operationalization. By our definition only radical innovations are new to the world. However, all innovations can be evaluated based on their newness to the industry and newness to the firm using our conceptualization. New to the world implies new to the industry and new to the firm. For 
this reason it is not valid to include newness to the world in determining product innovativeness of different types of innovations. Newness to the world could be used as a measure when studying radical innovations alone, but is not necessary in order to describe really new or incremental innovations.

Thus, at the first-order on a macro level for product innovativeness of an innovation,

P1a: The greater the discontinuity in the industry's marketing S-curve, the higher the degree of newness of the innovation.

P1b: The greater the discontinuity in the industry's technology S-curve (dissemination curve), the higher the degree of newness of the innovation.

Likewise at the first-order on a micro level,

P2a: The greater the discontinuity in the firm's marketing knowledge, the higher the degree of newness of the innovation to the firm.

P2b: The greater the discontinuity in the firm's technology knowledge, the higher the degree of newness of the innovation to the firm.

\subsection{Second-order factor}

The second-order factor shows the formative conceptualization of the macro and micro perspective of product innovativeness. The greater the newness of the product innovation to the industry, the higher the product innovativeness. The greater the newness of the product innovation to the firm, the higher the product innovativeness. Failure to evaluate both of these factors in the modeling of product innovativeness will result in fatal errors to content validity. An innovation should never be evaluated for its innovativeness based on only a macro or micro level. Thus,

P3a: A positive relationship exists between an innovation's newness to the industry and its degree of product innovativeness.

P3b: A positive relationship exists between an innovation's newness to the firm and its degree of product innovativeness.

\subsection{Newness to the customer}

We have modeled newness to the customer as a reflective construct to product innovativeness. A product's innovativeness classification is never dependent upon the viewpoint of the customer. This is an error of reversal of causal inferences. The goal of identifying innovation typologies is to build an understanding of how the firm must approach the development process of new products. Thus, to use the customer's perspective for identifying products would be liken as letting the customer drive the innovative process of the firm. This viewpoint is not to be confused with completely ignoring the customer when identifying innovation types. The customer perspective is considered as the firm evaluates its market strategy of innovative products. Thus,

P4: A positive relationship exists between product innovativeness and newness to the customer.

Our seven research propositions fit the broad framework depicted in Fig. 2. It facilitates parsimonious conceptualization and, more importantly, offers an operationalization that may be easily tested. This single construct 'product innovativeness' for technology-based projects can be utilized as a mediating or moderating variable or it can also be used to split innovations into product type categories. We also suggest measures for testing this model based on extant literature (Table 6).

\section{Conclusions and future research}

Once the 'name game' is resolved by allowing studies on innovations to be evaluated along common dimensions, it is revealed that few empirical studies have identified the idiosyncrasies of the development process for radical and really new innovations. We find considerable anecdotal evidence that radical innovations require unique and sophisticated development strategies, but little empirical evidence to support these theories. It has been shown empirically that radical products entail greater risk [30,41,45], product champions are more valuable in the radical development process [35,37], and radical innovation are best identified using both a technological and business perspective [22]. It is just these few studies that have put the 'radical innovation' as the primary emphasis. Four additional studies [4,7, 30,55] labeled innovations as 'radical', however, the definitions provided for 'radical innovations' and the projects sampled could be considered 'really new innovations' as they have been identified in this review. Thus, it is uncertain if the findings in these four studies are relevant only to radical innovation or to both radical and really new innovations.

The Journal of Product Innovation Management's May 1998 Special Issue has contributed to half of the existing empirically supported knowledge regarding really new innovations. Song and Montoya-Weiss [54] conducted an extensive study on the key differences in determinants of new product success between really new and incremental products. Really new product successes are positively impacted by increasing the proficiency level of strategic planning activities, whereas, working to improve proficiency in business and market opportunity analysis is counter productive for really new products. Other researchers have found that customer research is critical in the early development stages in order to assess the types and degrees of discontinuities inherent in really new innovations [61]. Additionally, managers are more likely to carry a risky NPD project through commercialization when the product is really new than when it is less innovative [50]. Although Colarelli 
Table 6

Possible measures to use in empirical analysis

\begin{tabular}{|c|c|}
\hline Micro-level/marketing measures & Source \\
\hline 1. Customers/clients totally new to the firm & - Cooper (1979) \\
\hline 2. New market approach (customer contact, advertising promotion etc.) & - Cooper (1979) \\
\hline 3. New competitors for the firm & - Cooper (1979) \\
\hline 4. Product use (needs served) new to the firm & - Cooper (1979) \\
\hline 5. Class of service/product totally new to the firm & - Cooper \& de Brentani (1991) \\
\hline 6. Improvements/revisions to existing company products & - Cooper \& de Brentani (1991) \\
\hline 7. Satisfies clearly identified customer/client need & - Cooper \& de Brentani (1991) \\
\hline 8. Fit with managerial skills and preferences/expertise/resource capabilities & - Cooper \& de Brentani (1991) \\
\hline 9. Firm's prior experience for selling product in this line of business & - Green, Gavin, \& Aiman-Smith (1995) \\
\hline 10. Product/service was more complex than we have introduced into the same market & - Atuahene-Gima (1995) \\
\hline 11. Responds to important changes in customer needs/wants & - Cooper \& de Brentani (1991) \\
\hline 12. The product technology is new to the customer & - Ali, Krapfel, \& LaBahn (1995) \\
\hline Micro-level/technology measures & Source \\
\hline 13. Newness of the technology: how large is required technology change in order to develop the product & - Goldenberg, Lehman, \& Mazursky (1999) \\
\hline 14. Science and technology knowledge base newness to firm’s R\&D & - Green, Gavin, \& Aiman-Smith (1995) \\
\hline 15. Production process new to the firm & - Cooper (1979) \\
\hline 16. Product technological newness to the firm & - Green, Gavin, \& Aiman-Smith (1995) \\
\hline 17. Modification of technology currently in use at the firm & - Colarelli O’Connor (1998) \\
\hline 18. Degree of difference for other products in technical characteristics or specifications & - Lee \& Na (1994) \\
\hline 19. Complexity of manufacturing technology & - More (1982) \\
\hline Macro-level/marketing measures & Source \\
\hline 20. New to the world & - Atuahene-Gima (1995) \\
\hline 21. Totally new competitive environment & - Cooper \& de Brentani (1991) \\
\hline 22. Consistent with existing customer values/operating systems & - Souder \& Song (1997) \\
\hline 23. Existence of potential demand only (no actual demand) & - Cooper (1979) \\
\hline 24. Newness to the market & - Cooper (1979) \\
\hline Macro-level/technological measures & Source \\
\hline 25. Science \& technology (S\&T) state of art within general scientific community & - Green, Gavin, \& Aiman-Smith (1995) \\
\hline 26. Level of S\&T knowledge base within the general scientific community & - Green, Gavin, \& Aiman-Smith (1995) \\
\hline 27. Predictability of progress in S\&T knowledge area within general scientific community & - Green, Gavin, \& Aiman-Smith (1995) \\
\hline 28. Modification of technology used in other industries & - Colarelli O’Connor (1998) \\
\hline 29. Improvement/modification of technology in use elsewhere in the industry & - Colarelli O’Connor (1998) \\
\hline $\begin{array}{l}\text { 30. Innovation incorporates a substantially different core technology relative } \\
\text { to the previous product generation }\end{array}$ & - Chandy \& Tellis (2000) \\
\hline
\end{tabular}

O'Connor [10] used the label 'discontinuous', it can be concluded that market learning for really new innovations differ drastically from those associated with conventional new product development processes.

Four additional studies explored the differences between really new innovations and incremental innovations. Although the innovations were labeled 'original new products' [64], 'significant innovations' [37], 'moderately innovative' [31], and 'medium newness to the firm' [20], all these can be considered really new innovations. These studies reveal that really new products are more diversification oriented [64], that success can be increased by delaying launch [64], and that managerial sponsorship is important for really new innovations [37]. Kleinschmidt and Cooper [31] and Goldenberg, et al [20] found contradictory results. By the Kleinschmidt and Cooper definition, moderately innovative products are not as successful as highly innovative or low innovative products, (a U-shaped relationship exists between innovativeness and success). Goldenberg, et al report that successful products tend to be moderately new to the market, but not new to the firm. These varying results appear to be symptomatic of the different definitions used for moderately innovative products.

We believe that the inconsistencies in labeling and operationalizing innovations in the new product literature may have contributed to the slow progression of knowledge in these areas. Using a critical review of the new product development literature in the marketing, management and engineering disciplines, we have suggested a typology for labeling innovation types and a method of operationalizing product innovativeness. Our propositional inventory and integrative framework represent efforts to build a foundation for the systematic development of a theory-based definition of product innovativeness. Additional research is needed to empirically test this proposed operationalization. However, we believe a framework is now in place for researchers to provide continuity to their definition of product innovativeness.

'Incremental innovations' incorporate product improvements (features, benefits, price, manufacturing, process) 
into innovations using existing technologies targeted towards existing markets. On a macrolevel, 'really new' product innovations result in either market discontinuities or technology discontinuities but not both, and result in both types of discontinuities on a microlevel. Really new products include new technologies to existing markets (product line extensions or new product lines) or existing technologies to new markets (also new product lines). Most new product innovations will fall into one of these two categories. On a rare occasion, a radical innovation will emerge. It will result in discontinuities in both the existing market structure and the existing technology structure. Radical innovations result in the creative destruction or envelopment and suppression of the existing infrastructure. Examples include the steam engine, the World Wide Web and the Bessemer steel manufacturing process.

How innovations are labeled is important if researchers want to increase their understanding of the development process of different types of innovations. Future research is needed to determine how really new product innovations differ from radical innovations in altering the new product development process. Because of the rarity of radical innovations, this may be difficult to accomplishment without reaching back into history. The goal for future researchers should be to help practitioners identify how the characteristics of radical new products, compared to really new products, will alter the new product development process. Radical innovations can rarely be planned; it is through the creativity and genius of innovators and marketers that they evolve into commercialized products. Researchers can help this process by identifying how to take that rare rose and give it a distinct place in the litany of innovations.

Another area for future research concerns the term 'technology'. Research is needed to determine how 'technolog- ical' innovations are identified in the new product development literature. Again, many researchers have varying definitions of what is considered a technological innovation. Congruence in understanding what realm of new products should be considered 'technological' will also greatly increase our knowledge of the innovation process.

\section{Notes}

1. Rosanna Garcia is a doctoral candidate in Marketing \& Supply Chain at Michigan State University. Her research interests are in new product development and complex systems. Prior to joining academia, she worked as a new product manager in the telecommunications industry for several years.

2. Roger Calantone is the Eli Broad Professor of Marketing and Product Innovation at Michigan State University. His research interests include the study of the new product development processes, the management of technology and the manufacturing and engineering interface. He has published in several journals including the Journal of Marketing, the Journal of Marketing Research, the Journal of Product Innovation Management, Management Science and Marketing Science.

\section{Acknowledgments}

The authors would like to acknowledge participants at the 1999 PDMA International Conference for comments on an earlier version of this manuscript. We would also like to thank two reviewers, as well as the editor of JPIM, for their helpful comments. Special thanks goes to Paul Rummel for his assistance with modeling Boolean logic. 
Appendix A

Micro-level / Marketing Measures

1. Customers/clients totally new to the firm

2. New market approach (customer contact, advertising promotion etc.)

3. New competitors for the firm

4. Product use (needs served) new to the firm

5. Product lets customer reduce his costs

6. Product higher quality than competitors

7. Class of service/product totally new to the firm

8. Improvements/revisions to existing company products

9. Satisfies clearly identified customer/client need

10. Fit with managerial skills and preferences/expertise/resource capabilities

11. Similarity of distributors

12. Suitability of sales force

13. To what extent does this product fit established business practices of firm [right in line -- dramatic departure]

14. Firms prior experience for selling product in this line of business [extensive -nil]

15. Cost reductions to existing company products

16. It required a major learning effort or experience by customers

17. The product/service concept was difficult for customers to evaluate or understand

18. It required considerable advance planning by customers before use

19. It involved a high change over cost for the customer

20. Product/service was more complex than we have introduced into the same market

21. Superior to competing products in meeting customer needs/provides greater benefits

22. Responds to important changes in customer needs/wants

23. The product technology is new to the customer

24. Product had unique features for customer
Example of use in:

- Cooper (1979)

- Cooper (1979)

- Cooper (1979)

- Cooper (1979)

- Cooper (1979)

- Cooper (1979)

- Cooper \& de Brentani (1991)

- Cooper \& de Brentani (1991)

- Cooper \& de Brentani (1991)

- Cooper \& de Brentani (1991)

- More (1982)

- More (1982)

- Green, Gavin, \& Aiman-Smith (1995)

- Green, Gavin, \& Aiman-Smith (1995)

- Kleinschmidt \& Cooper (1991)

- Atuahene-Gima (1995)

- Atuahene-Gima (1995)

- Atuahene-Gima (1995)

- Atuahene-Gima (1995)

- Atuahene-Gima (1995)

- Chandy \& Tellis (2000)

- Cooper \& de Brentani (1991)

- Ali, Krapfel, \& Labahn (1995)

- Ali, Krapfel, \& Labahn (1995)
Micro-level / Technology Measures

25. Newness of the technology: how large is required technology change in order to develop the product, or to manufacture it

26. Production process new to the firm

27. R\&D actual experience with science and technology (S\&T) knowledge base within firm's R\&D [vast - nil]

28. Cost for firm to do R\&D in S\&T knowledge base within firm's R\&D [low high]

29. Familiarity with S\&T knowledge base within firm's R\&D [familiar unfamiliar]

30. Modification of technology currently in use at the firm

31. Degree of difference for other products in technical characteristics or
Example of use in:

- Goldenberg, Lehman, \& Mazursky (1999)

- Cooper (1979)

- Green, Gavin, \& Aiman-Smith (1995)

- Green, Gavin, \& Aiman-Smith (1995)

- Green, Gavin, \& Aiman-Smith (1995)

- Colarelli O'Connor (1998)

- Lee \& Na (1994) 
specifications

32. Complexity of manufacturing technology

- More (1982)

Macro-Level/Marketing Measures

Example of use in:

33. New to the world

34. Totally new competitive environment

- Atuahene-Gima (1995)

35. Consistent with existing customer values/operating systems

- Cooper \& de Brentani (1991)

36. Existence of potential demand only (no actual demand)

- Souder \& Song (1997)

37. Newness to the market

- Cooper (1979)

- Cooper (1979)

Macro-Level/Technical Measures

Example of use in:

38. Science \& technology (S\&T) state of art within general scientific community [developed - embryonic]

- Green, Gavin, \& Aiman-Smith (1995)

39. Level of S\&T knowledge base within the general scientific community [certain - uncertain]

- Green, Gavin, \& Aiman-Smith (1995)

40. Entry into S\&T knowledge base within general scientific community [easy - difficult]

- Green, Gavin, \& Aiman-Smith (1995)

41. Rate of entry into science and technology knowledge area within general scientific community [slow -rapid]

- Green, Gavin, \& Aiman-Smith (1995)

42. Predictability of progress in S\&T knowledge area within general scientific community [slow - rapid]

- Green, Gavin, \& Aiman-Smith (1995)

43. Cost of doing research in S\&T knowledge area within general scientific community [predictable - unpredictable]

- Green, Gavin, \& Aiman-Smith (1995)

44. Cost for new firms to enter S\&T knowledge base within the general scientific community [low - high]

45. Progress in S\&T knowledge area within general scientific community [minor - major improvements]

46. Cost of doing research in knowledge area within general scientific community [not very - extremely]

47. Combinations of multiple developing technologies

- Green, Gavin, \& Aiman-Smith (1995)

- Green, Gavin, \& Aiman-Smith (1995)

- Green, Gavin, \& Aiman-Smith (1995)

- Colarelli O'Connor (1998)

48. Modification of technology used in other industries

- Colarelli O'Connor (1998)

49. Improvement/modification of technology in use elsewhere in the industry

- Colarelli O'Connor (1998)

50. Innovation incorporates a substantially different core technology relative to the previous product generation

51. Type of work done on the project ranging from pure applications engineering to the development or application of new technology

- Chandy \& Tellis (2000)

- Kessler \& Chakrabarti (1999) 
Appendix B: Boolean Logic for Identifying Innovation Type

Input: 1=present

Output: 1=postive identification

$0=$ not $0=$ negative identification

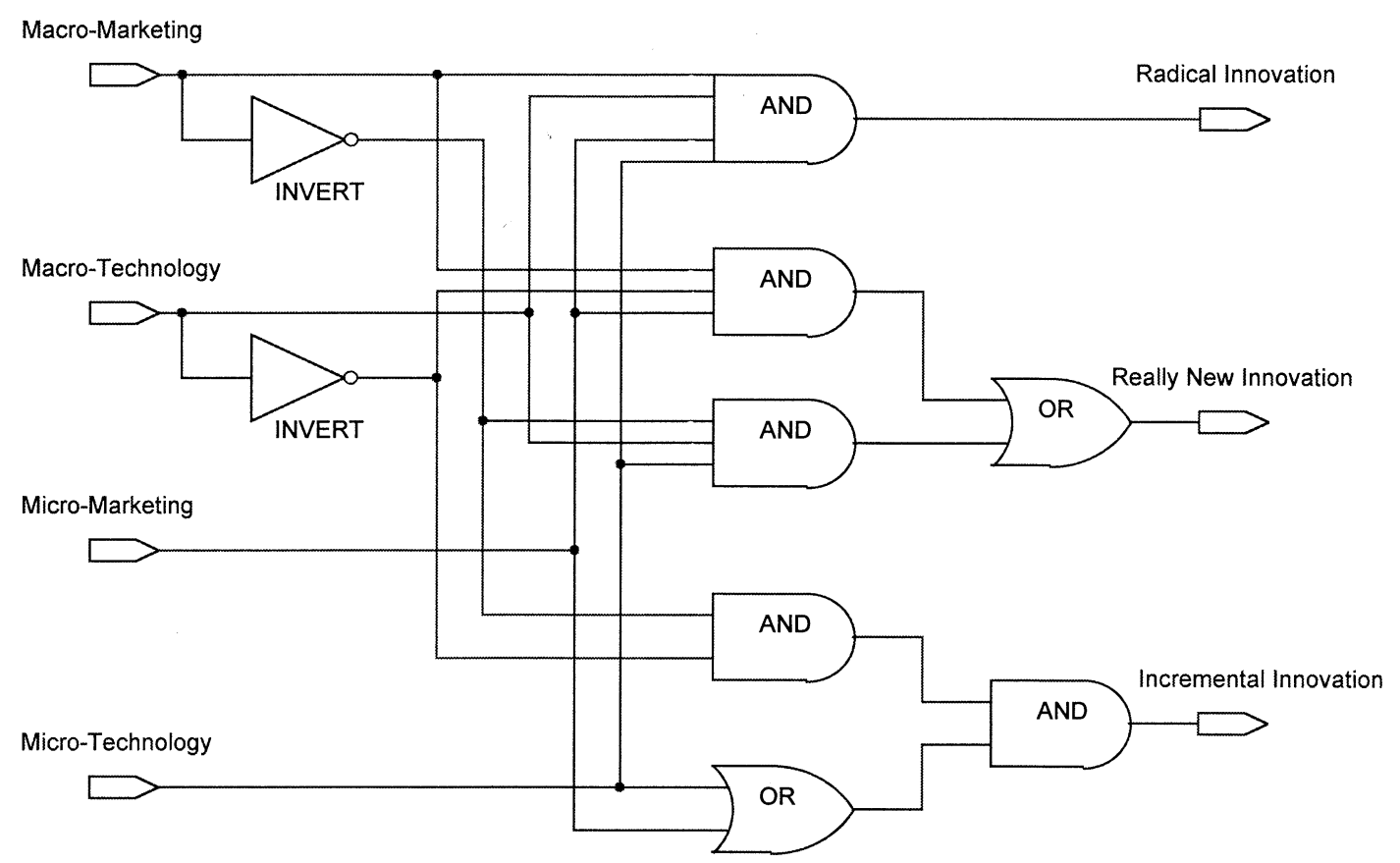

Inputs*: Discontinuities

Outputs: Innovation Type

\begin{tabular}{|l|l|l|l||l|l|l|}
\hline \hline $\begin{array}{l}\text { Macro- } \\
\text { Marketing } \\
\text { Discontinuity }\end{array}$ & $\begin{array}{l}\text { Macro- } \\
\text { Technology } \\
\text { Discontinuity }\end{array}$ & $\begin{array}{l}\text { Micro- } \\
\text { Marketing } \\
\text { Discontinuity }\end{array}$ & $\begin{array}{l}\text { Micro- } \\
\text { Technology } \\
\text { Discontinuity }\end{array}$ & $\begin{array}{l}\text { Radical } \\
\text { Innovation }\end{array}$ & $\begin{array}{l}\text { Really New } \\
\text { Innovation }\end{array}$ & $\begin{array}{l}\text { Incremental } \\
\text { Innovation }\end{array}$ \\
\hline 1 & 1 & 1 & 1 & 1 & 0 & 0 \\
\hline 1 & 0 & 1 & 0 & 0 & 1 & 0 \\
\hline 0 & 1 & 0 & 1 & 0 & 1 & 0 \\
\hline 1 & 0 & 1 & 1 & 0 & 1 & 0 \\
\hline 0 & 1 & 1 & 1 & 0 & 1 & 0 \\
\hline 0 & 0 & 1 & 1 & 0 & 0 & 1 \\
\hline 0 & 0 & 1 & 0 & 0 & 0 & 1 \\
\hline 0 & 0 & 0 & 1 & 0 & 0 & 1 \\
\hline
\end{tabular}

*note: other combinations are not feasible, if an innovation results in a discontinuity on a macro-level, the discontinuity will also occur on a micro-level.

\section{References}

[1] Abernathy WJ, Clark KB. Innovation. mapping the winds of creative destruction. Research Policy 1985;14(1):3-22.

[2] Ali A, Krapfel R, LaBahn D. Product innovativeness and entry strategy: impact on cycle time and break-even time. Journal of Product Innovation Management 1995;12:54-69.

[3] Anderson P, Tushman ML. Technological discontinuities and dominant designs: a cyclical model of technological change. Administrative Science Quarterly 1990;35:604-33.
[4] Atuahene-Gima K. An exploratory analysis of the impact of market orientation on new product performance: a contingency approach. Journal of Product Innovation Management 1995;12:27593.

[5] Balachandra R, Friar JH. Factors in success in r\&d projects and new product innovation: a contextual framework. IEEE Transactions on Engineering Management 1997;44(3):276-87.

[6] Booz-Allen Hamilton. New products management for the 1980s. New York: Booz-Allen Hamilton Inc. 1982. 
[7] Chandy RK, Tellis GJ. The incumbents curse: incumbency, size, and radical product innovation. Journal of Marketing 2000;64:1-17.

[8] Cheng CH, Kumar A, Motwani JG, Reisman A, Madan MS. A citation analysis of the technology innovation management journals. IEEE Transactions on Engineering Management 1999;46(1):4-13.

[9] Christensen CM. The innovator's dilemma: when new technologies cause great firms to fail. Boston, MA: Harvard Business School Press. 1997. p. 1-225.

[10] Colarelli O'Connor G. Market learning and radical innovation: a cross case comparison of eight radical innovation projects. Journal of Product Innovation Management 1998;15(2):151-66.

[11] Cooper RG. The dimensions of industrial new product success and failure. Journal of Marketing 1979;43:93-103.

[12] Cooper RG, de Brentani U. New industrial financial services: what distinguishes the winners. Journal of Product Innovation Management 1991;8:75-90.

[13] Damanpour F. Organizational innovation: a meta-analysis of effects of determinants, and moderators. Academy of Management Journal 1991;34(3):555-90.

[14] Dickson PR. Toward a general theory of competitive rationality. Journal of Marketing 1992;56(1):69-82.

[15] Ettlie JE, Rubenstein AH. Firm size and product innovation. Journal of Product Innovation Management 1987;4:89-108.

[16] Ettlie JE, BridgesWP, O'Keefe RD. Organization strategy and structural differences for radical versus incremental innovation. Management Science 1984;30:682-95.

[17] Foster RN. Innovation, the attacker's advantage. New York: Summit, 1986.

[18] Freeman C. Critical survey: the economics of technical change. Cambridge Journal of Economics 1994;18(5):463-514.

[19] Freeman C. The nature of innovation and the evolution of the productive system. In: OECD, editors. Technology and productivity-the challenge for economic policy. Paris: OECD, 1991. p. 303-14.

[20] Goldenberg J, Lehmann DR, Mazursky D. The primacy of the idea itself as a predictor of new product success. Marketing Science Institute Working Paper, 1999.

[21] Green SG, Gavin MB, Aiman-Smith L. Assessing a multidimensional measure of radical technological innovation. IEEE Transactions on Engineering Management 1995;42(3):203-14.

[22] Griffin A. PDMA research on new product development practices: updating trends, and benchmarking best practices. Journal of Product Innovation Management 1997;14:429-58.

[23] Grossman JB. The supreme court and social change: a preliminary inquiry. American Behavioral Scientist 1970;13:535-51.

[24] Grupp H. Foundations of economics of innovation: theory, measurement, and practice. Northampton, MA: Edward Elgar Publishing Ltd., 1998.

[25] Henard D, Szymanski DM. Why are some new products more successful than others? A meta-analysis of the empirical evidence" : Texas A\&M University, forthcoming.

[26] Heany DF. The degrees of product innovation. The Journal of Business Strategy 1983;3(4):3-14.

[27] Henderson RM, Clark KB. Architectural innovation: the reconfiguration of existing product technologies, and the failure of established firms. Administrative Science Quarterly 1990;35:9-30.

[28] Johne FA, Snelson PA. Success factors in product innovation: a selective review of the literature. Journal of Product Innovation Management 1988;5:114-28.

[29] Johnson SC, Jones C. How to organize for new products. Harvard Business Review 1957;5-6:49-62.

[30] Kessler EH, Chakrabarti AK. Speeding up the pace new product development. Journal of Product Innovation Management 1999;16: 231-47.

[31] Kleinschmidt EJ, Cooper RG. The impact of product innovativeness on performance. Journal of Product Innovation Management 1991;8: $240-51$.
[32] Kusunoki K. Incapability of technological capability: a case study on product innovation in the japanese facsimile machine industry. Journal of Product Innovation Management 1997;4:368-82.

[33] Lawton L, Parasuraman A. The impact of the marketing concept on new product planning. Journal of Marketing 1980;44:19-25.

[34] Layton E. Conditions of technological development. In: de Solla Price D, Spiegel-Rosing ID. Science, technology, and society, Beverly Hills, CA: Sage Publications, 1977.

[35] Lee M, Na D. Determinants of technical success in product development when innovative radicalness is considered. Journal of Product Innovation Management 1994;11:62-8.

[36] Leonard-Barton D, Wilson E. Commercializing technology: imaginative understanding of user needs. Case study N9-694-102. Cambridge, MA: Harvard Business School, 1994.

[37] Maidique MA, Zirger BJ. A study of success, and failure in product innovation: the case of the US electronics industry. IEEE Transactions on Engineering Management. 1984; EM-31(4):192-203.

[38] Meyers PW, Tucker FG. defining roles for logistics during routine and radical technological innovation. Journal of Academy of Marketing Science 1989;17(1):73-82.

[39] Miles RE, Snow CC. Organizational strategy, structure, process. New York: McGraw-Hill Publishing Company, 1978.

[40] Mishra S, Kim D, Lee DH. Factors affecting new product success: cross country comparisons. Journal of Product Innovation Management 1996;13:530-50.

[41] More RA. Risk factors in accepted and rejected new industrial products. Industrial Marketing Management 1982;11:9-15.

[42] Moriarty RT, Kosnik TJ. High-tech concept, continuity, and change. IEEE Engineering Management Review 1990;3:25-35.

[43] Normann R. Organizational innovativeness: product variation, and reorientation. Administrative Science Quarterly 1971;16:203-15.

[44] OECD. The nature of innovation and the evolution of the productive system. technology and productivity-the challenge for economic policy. Paris: OECD, 1991. p. 303-14.

[45] Olson EM, Walker OC, Ruekert RW. Organizing for effective new product development: the moderating role of product innovativeness. Journal of Marketing 1995;59:48-62.

[46] Rice MP, Colarelli O'Connor G, Peters LS, Morone JG. Managing discontinuous innovation. Research Technology Management 1998; 41(3):52-8.

[47] Robertson TS. The process of innovation and the diffusion of innovation. Journal of Marketing 1967:31:14-9.

[48] Rogers EM. Diffusion of innovations. New York: The Free Press, 1995.

[49] Rothwell R, Gardiner P. Reinnovation and robust designs: producer and user benefits. Journal of Marketing Management 1988;3(3):37287.

[50] Schmidt JB, Calantone RJ. Are really new product development projects harder to shut down? Journal of Product Innovation Management 1998;15(2):111-23.

[51] Schumpeter JA. Business cycles: a theoretical, historical, and statistical analysis of the capitalist process. Vol. 2. New York: McGraw Hill, 1939.

[52] Schumpeter JA. The theory of economic development. Cambridge, MA: Harvard University Press, 1934. [English translation from German edition, Leipzig 1912].

[53] Smith BLR, Barfield CE. Technology, R\&D, and the economy. Washington, DC: The Brookings Institution, 1996.

[54] Song MX, Montoya-Weiss MM. Critical development activities for really new versus incremental products. Journal of Product Innovation Management 1998;15(2):124-35.

[55] Souder WE, Song MX. Contingent product design, and marketing strategies influencing new product success, and failure in US, and Japanese electronic firms. Journal of Product Innovation Management 1997;14:21-34. 
[56] Stobaugh R. Innovation, and competition: the global management of petrochemical products. Boston, MA: Harvard Business School Press, 1988.

[57] Tidd J. Development of novel products through intraorganizational, and interorganizational networks: the case of home automation. Journal of Product Innovation Management 1995;12:307-22.

[58] Tushman ML, Anderson P. Technological discontinuities and organizational environments. Administrative Science Quarterly 1986;31: 439-65.

[59] Utterback JM. Mastering the dynamics of innovation. Boston, MA: Harvard Business School Press, 1996.

[60] Utterback JM, Abernathy WJ. A dynamic model of process, and product innovation. Omega 1975;33:639-56.

[61] Veryzer RW. Key factors affecting customer evaluation of discontinuous new products. Journal of Product Innovation Management 1998; 15(2):136-50.

[62] Wheelwright SC, Clark KB. Revolutionizing product development. New York: Free Press, 1992.

[63] Wind Y, Mahajan V. New product development process: a perspective for reexamination. Journal of Product Innovation Management 1988;15(2):34-310.

[64] Yoon E, Lilien GL. New industrial product performance: the effect of market characteristics and strategy. Journal of Product Innovation Management 1985;3:134-44. 